\title{
Evaluation of subsurface irrigation on microorganism contamination of romaine lettuce
}

\author{
Rocio G. Reyes Esteves1*, Charles P. Gerba2, Donald C. Slack1 \\ ${ }^{1}$ University of Arizona, Department of Biosystems Engineering. 1177 E. 4th Street, Shantz Building, \\ Room 403. Tucson, AZ, USA 85721. \\ ${ }^{2}$ University of Arizona, Department of Environmental Science. 1177 E. Lowell Street, \\ Animal and Comparative Biomedical Sciences Building, Room 211. Tucson, AZ, USA \\ 85721.
}

\begin{abstract}
The use of contaminated water to irrigate crops by surface, sprinkler, or conventional drip irrigation represents a significant public health concern due to the presence of multiple microbial pathogens associated with gastrointestinal disease. In this study, Escherichia coli and MS2 bacteriophage were used as microbial surrogates to evaluate the contamination of romaine lettuce (Lactuca sativa L. var. longifolia) using bottom watering pots simulating a subsurface drip irrigation (SDI) system in a greenhouse. The primary goal was to determine whether the exposure of lettuce plants to $E$. coli and MS2 would result in detectable levels of these microorganisms associated with the edible portions of plants. Plants were grown in bottom watering pots and were irrigated the last twelve days before harvesting with contaminated water containing $E$. coli and MS2 phage at $10^{9}$ $\mathrm{CFU} / \mathrm{ml}$ and $10^{11} \mathrm{PFU} / \mathrm{ml}$, respectively. Harvested plants were processed to determine if $E$. coli or MS2 was associated with the plant surfaces or within the plant tissues. None of the samples was positive for either E. coli or MS2 bacteriophage, suggesting that subsurface irrigation systems effectively reduce the risk of produce-contamination with bacterial and viral pathogens.
\end{abstract}

\section{Introduction}

Foodborne illness outbreaks linked to the consumption of contaminated leafy greens continues not only in the United States but also throughout the world [1]. It has been demonstrated that crops irrigated with wastewater may become contaminated with enteric bacteria and viruses. One of the most common agents associated with these outbreaks is Escherichia coli O157:H7. Many of these outbreaks have been associated with lettuce. For example, in 2018, a total of 210 cases, including 96 hospitalizations and five deaths, were linked to the consumption of romaine lettuce from the Yuma AZ growing region [2]. Contaminated water, soil amendments, flooding of fields, and cattle are all likely sources of contamination of lettuce [3]. The ability of $E$. coli to contaminate the tissue of lettuce plants has been explained [4 - 6]. Researchers have suggested that E. coli can be taken up by the roots and transported to the edible portion of a lettuce plant [4],[7-8]. Solomon et al. [4] reported the internalization of $E$. coli $\mathrm{O} 157: \mathrm{H} 7$ into edible tissue of lettuce, detected by laser scanning confocal microscopy, through root-associated uptake of the pathogen. Other 
researchers report contradictory outcomes such as association with root tissue, but not within edible tissue [9-10].Several variables including plant age, soil type, growth conditions (e.g., hydroponics versus soil), method of exposure, and lettuce variety may influence whether enteric pathogens will enter a plant through the root system and migrate to the above-ground portions of plants [11],[6]. For instance, a study demonstrated that the population of E. coli O157:H7 was consistently higher on young, inner leaves as compared with older, middle leaves of lettuce [12].

Similarly, enteric viruses are also one of the most typical causes of gastroenteritis worldwide. It has been reported than the $60 \%$ of U.S. foodborne outbreaks are associated with the consumption of leafy greens were caused by viruses, while E. coli each only accounted for $10 \%$ of outbreaks [13]. Enteric viruses can be transmitted by food, water, fomites, and human contact [14]. Enteric viruses present in the water used for irrigation can remain infectious from 3 to 5 weeks on irrigated crops [15-16]. Even though enteric viruses do not survive well on crop surfaces because of solar irradiation, desiccation, and high temperatures, they can remain infectious up to 60 days in covered parts of the plants such as the roots, closed foliage parts, and plant tissues parts of the plants [17].

Given the lack of convincing data concerning the plant internalization of enteric foodborne pathogens, whether through the roots or stomata in the edible tissue of growing plants, the cultivation of crops irrigated with water containing populations of bacteria and virus should be considered a potential human health risk. Indeed, exposure to growing crops to any level of the pathogen is unacceptable. However, subsurface irrigation systems like subsurface drip irrigation (SDI) offers an attractive alternative to irrigation with low-quality water that may contain pathogens of various types, without increasing the risk to public health. Since subsurface water does not reach the upper soil layers, this reduces the chances of direct contact of pathogens in the effluent with aerial parts of the plants [18]. Subsurface irrigation may also allow the use of effluents of inferior quality, with the soil serving as a barrier to microbial pathogens. Nevertheless, the level of protection provided by subsurface and SDI needs to be evaluated.

Thus, the objective of this study was to determine the effectiveness of subsurface irrigation systems concerning their capability to prevent contamination of the above-ground edible portion of the plant, by using nonpathogenic microbial surrogates, MS2 bacteriophage and Escherichia coli ATCC 25922, during irrigation of romaine lettuce with contaminated water. The authors decided to utilize surrogates because safety is the primary benefit of using nonpathogenic surrogates. Surrogates are defined as organisms, particles, or substances used to study the fate of a pathogen in a specific environment [19]. They are similar in structure, such as size and composition, to viruses and bacteria that infect both humans and animals. It is often inappropriate to use real target pathogens due to fears of possible risks. The use of viruses may represent a potential health hazard that severely limits their use in environmental research [20].

\section{Materials and Methods}

\subsection{Greenhouse preparation and lettuce plant cultivation}

Lettuce was cultivated from October 23, 2019, to December 02, 2019, in a greenhouse located at the experimental station at the 6th Street Garage of the University of Arizona. Six benches were utilized. A total of seventy-two bottom watering pots with a lettuce plant (samples) were used, Figure. 1. Bottom watering pots simulated a subsurface drip irrigation system (SDI) with drip tapes installed at a depth of $20 \mathrm{~cm}$. Each pot was filled to a depth of $20 \mathrm{~cm}$ with Gila loam soil, which was covered with a $5 \mathrm{~cm}$ layer of fine sand to serve as a barrier 
against water rising to the soil surface. Gila loam is a soil typical of the type used for crop production in Arizona. Gila loam soil was collected during the fall season from the Campus Agricultural Center of the University of Arizona in Tucson. It was taken from the top $20 \mathrm{~cm}$ of the field with a shovel. Large rocks and plant debris were removed. The fine sand soil was purchased from a local Lowe's store in Tucson. The first 36 pots (samples) served as the control group and were irrigated with tap water. The remaining 36 samples were used as the treatment group and were irrigated with contaminated water containing a concentration of $10^{9} \mathrm{CFU}$ and $10^{11} \mathrm{PFU}$ per $\mathrm{ml}$ of E. coli and MS2 respectively. Romaine lettuce (Lactuca sativa L. var. longifolia) plant plugs were purchased from the Mesquite Valley Growers Nursery (Tucson, AZ). Plants were grown to 34 days of age in plugs at the nursery and then transplanted to the larger bottom watering pots as required in the greenhouse. Once plants were transplanted, they grew in the greenhouse at $\sim 27^{\circ} \mathrm{C}$ during the day and $\sim 11^{\circ} \mathrm{C}$ at night at the beginning of the season and $\sim 15^{\circ} \mathrm{C}$ during the day and $\sim 10^{\circ} \mathrm{C}$ at night at the end of the season. Lettuce was irrigated daily for ten days right after transplantation to avoid any water stress. The irrigation water was dechlorinated tap water neutralized with $10 \%$ sodium thiosulfate solution. Water was tested with a standard chlorine pool test kit to make sure that there was not any residual chlorination.
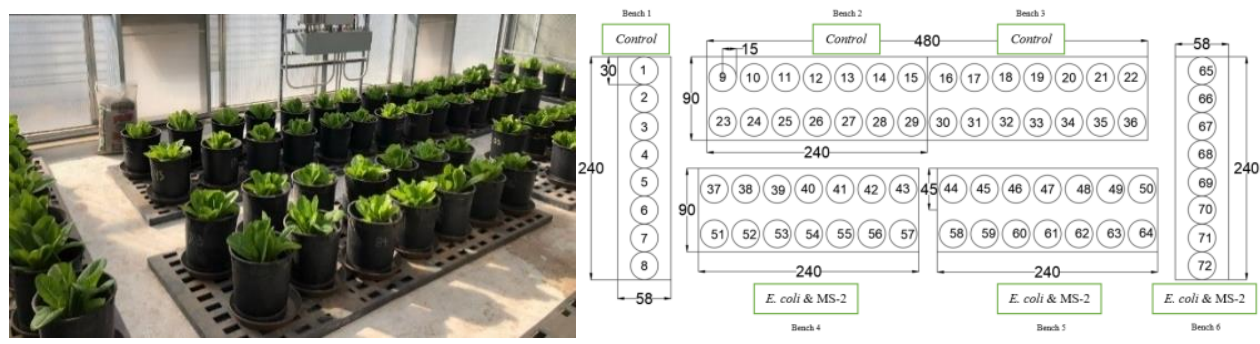

Fig. 1. Lettuces at the greenhouse and project floor plan (each number in a circle is a pot). Units in $\mathrm{cm}$.

Water $(300 \mathrm{ml})$ was applied directly to each saucer by using a watering can and a graduated cylinder. After the ten days of irrigation following transplantation, plants were irrigated when the soil subsurface started to dry. Moisture sensors were used all the time to measure the soil moisture to make sure that the top $5 \mathrm{~cm}$ of the soil always remained dry. Romaine lettuce reaches maturity between 60 and 80 days of growth. The experiments with contaminated water begun when the plants were fully developed. Lettuce plants were 62 days old when they were initially exposed to E. coli and MS2-contaminated irrigation water. Lettuce plants were irrigated $(300 \mathrm{ml})$ with water containing concentrations of $10^{9} \mathrm{CFU}$ of E. coli and $10^{11} \mathrm{PFU}$ of MS2 bacteriophage per $\mathrm{ml}$ the last twelve days before harvesting. The authors decided to irrigate these last twelve days of the growing season to expose the crop to the contaminated water, close to harvest when the plant is fully developed and ready to be eaten by consumers. For all experiments, the outer leaves were not prevented from touching the soil during the entire growing season. Lettuce plants were harvested on December 2, 2019 (74 days old), and right after harvesting were processed to determine whether E. coli or MS2 contamination was associated with the outer part or within plant tissue.

\subsection{Propagation of Microbial Surrogates}

Escherichia coli ATCC 25922 and MS2 bacteriophage were obtained from the University of Arizona Water \& Energy Sustainable Technology (WEST) Center. The media was supplied by the WEST Center as well. E. coli was grown overnight in $100 \mathrm{ml}$ tryptic soy broth (TSB) 
at $37^{\circ} \mathrm{C}$ incubator shaker for 24 hours using a freshly isolated colony from a plate. Overnight bacterial culture consistently resulted in a titer of approximately $10^{9} \mathrm{CFU}$ per $\mathrm{ml}$. Bacteriophage MS2 (male-specific, single-stranded RNA phage) was grown in the host bacteria strain Escherichia coli ATCC 15597 on November 19, 2019. MS2 phage was nonspecific to $E$. coli ATCC 25922. The total volume propagated was $40 \mathrm{ml}$. It was centrifuged at $4000 \mathrm{x}$ g for $20 \mathrm{~min}$. The total volume propagated with a concentration of $10^{11} \mathrm{PFU}$ per ml was suitable for the twelve days the experiment lasted. MS2 was stored at a temperature of $4^{\circ} \mathrm{C}$. It should be remarked that bacteriophages such as MS2 are frequently used as a surrogate for foodborne viruses in research on water and food systems [21]. MS2 bacteriophage represents a group of small RNA viruses $(23-30 \mathrm{~nm})$ with a size comparable to enteroviruses. The convenience of using bacteriophages over viruses is that the latter require sophisticated facilities and trained personnel to be propagated and tested. Furthermore, since bacteriophages only infect bacterial cells, they can be used safely in field studies, as was stated before.

Both surrogates, each E. coli overnight and a volume of $2 \mathrm{ml}$ of MS2, were mixed the day of their use in an autoclavable, sterile plastic bottle and stored at $4{ }^{\circ} \mathrm{C}$ until application. The mixtures were transported to the greenhouse in a cooler with ice as it was required every day. Then, surrogates were mixed vigorously with 20 -L of dechlorinated irrigation water in a 20 $\mathrm{L}$ carboy for $2 \mathrm{~min}$ to ensure even distribution. The 20-L carboy was previously washed with Liquinox liquid soap and rinsed with distilled water and neutralized with $20 \mathrm{ml}$ of $10 \%$ sodium thiosulfate solution for 10 minutes to remove any chlorine residues, each time before the experiment. Also, the irrigation (tap) water utilized was neutralized with $5 \mathrm{ml}$ of $10 \%$ sodium thiosulfate solution. The presence of chloride in irrigation water was always tested using a standard chlorine pool test kit prior to the preparation of the contaminated irrigation water. Background samples of irrigation water were collected every day. Plating dilutions on tryptic soy agar (TSA) plates confirmed microbial surrogates' levels in the water.

The first 36 pots (samples) were the control group, which means they were irrigated with "clean" water. The remaining 36 samples (treatment group) were irrigated with the contaminated water. The amount of clean and contaminated water applied to the pots for the last twelve days before harvesting was $300 \mathrm{ml}$. Water was applied with an autoclavable, sterile 1-L graduated cylinder directly to the saucers. Two graduated cylinders were used, one for irrigating the control group and another for irrigating the treatment group. The inoculum was applied carefully to prevent any splashing onto the edible portion of the plant. Pots irrigated with clean water (control group) were always irrigated first. After the irrigation with clean water, contaminated water was prepared, followed by the irrigation of the remaining 36 pots. Nitrile gloves were used all the time, e.g., during the preparation of the contaminated irrigation water and during the irrigation of both groups, to avoid crosscontamination. After each irrigation, the carboy was washed out with tap water, disinfected with a $30 \%$ solution of bleach for $10 \mathrm{~min}$, rinsed again, and finally neutralized with $20 \mathrm{ml}$ of $10 \%$ sodium thiosulfate solution.

\subsection{Sample Collection and Microbiological Analysis}

On the harvesting day, plants were picked by hand. The outer leaves were removed to model the harvest in-field conditions closely. A new pair of gloves was used for each sample to avoid cross-contamination. Each lettuce plant was stored in a labeled Ziploc bag and then transported in a cooler with ice from the greenhouse to the Environmental Microbiology Laboratory at the Water \& Energy Sustainable Technology (WEST) Center for their analysis. A total of seventy-two plants were planted. They were divided into two groups: control and treatment. Each group included thirty-six plants. Eighteen plants in each group were analyzed. The other half of plants from each group were saved as a backup, in case something 
did not work. Thus, from the thirty-six lettuce plants analyzed, eighteen belonged to the uninoculated control group, and the other eighteen to the treated group, Figure 2.

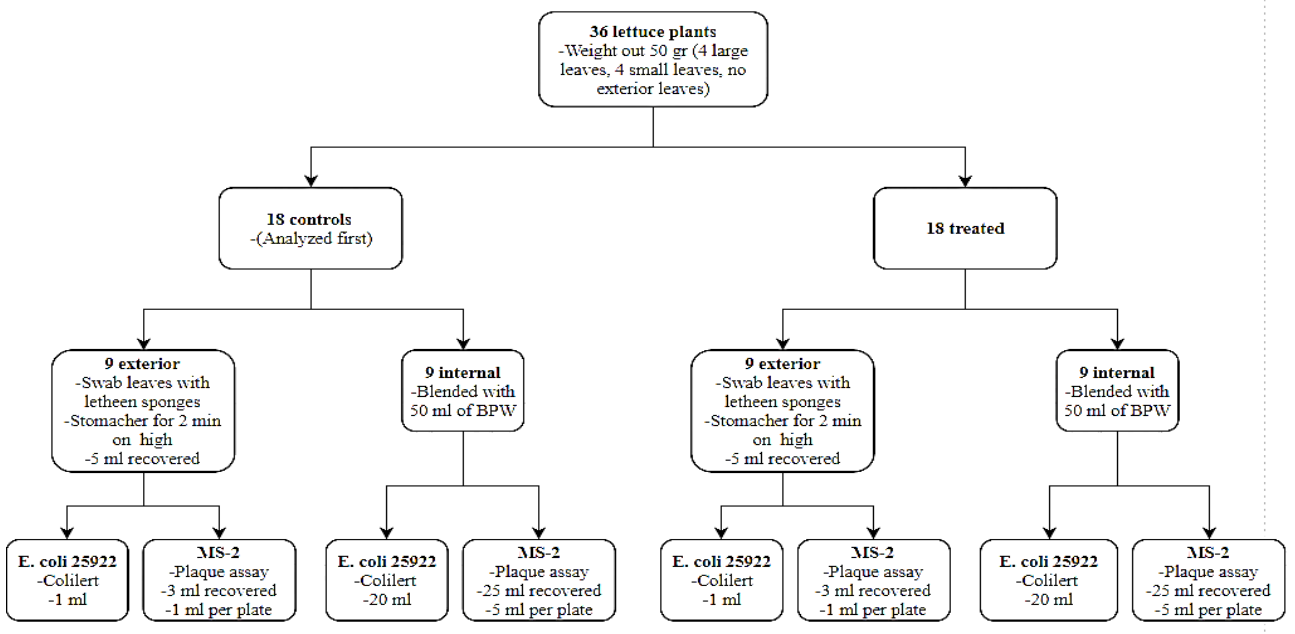

Fig. 2. Flowchart of the microbiology assay sample distribution.

Both plant surfaces and plant tissues from each lettuce plant (sample) were analyzed. 50 $\mathrm{g}$ of lettuce (about four large leaves and four small leaves) were weighed out from each Ziploc bag. The control group was analyzed first. The exterior locations were analyzed by swabbing all leaves from each sample with a Sponge-Stick with $10 \mathrm{ml}$ Letheen broth. Then, that sample of Letheen broth was homogenized in a stomacher for 2 minutes. A volume of $5 \mathrm{ml}$ of each sample was recovered. For the E. coli ATCC 25922 assay, $1 \mathrm{ml}$ was used in the Colilert Quanti-Tray/2000 system (IDEXX, Westbrook, Mass.). For the MS2 assay, $3 \mathrm{ml}$ were used for the Plaque assay method with the bacterial host E. coli ATCC 15597, using $1 \mathrm{ml}$ per plate. The plant tissues were analyzed by blending the same swabbed leaves with $50 \mathrm{ml}$ of buffer peptone water BPW in a blender for $2 \mathrm{~min}$. For the E. coli ATCC 25922 assay, $20 \mathrm{ml}$ were recovered and used in the Colilert Quanti-Tray/2000 system. For the MS2 assay, $25 \mathrm{ml}$ were recovered for the Plaque assay method using $5 \mathrm{ml}$ per plate. The same procedure was performed for the treated group. All microorganisms were incubated on their respective media for $24 \mathrm{~h}$ at $37^{\circ} \mathrm{C}$.

Two of the backup control samples were inoculated on purpose to visualize how the MS2 plaques would have looked, especially with the plant tissue. Hence, 200 ul of $10^{2}$ PFU of MS2 were spiked in $5 \mathrm{ml}$ of lettuce sample.

\section{Results and discussion}

None of the study microorganisms were recovered from lettuce surfaces (plant surfaces) and plant tissue, which was expected because lettuce never came into direct contact with the contaminated water; besides, the soil surface remained dry all the time. The water used to irrigate the lettuces had a good bacteriological quality. However, neither MS2 nor E. coli was detected in any lettuce sample collected in the cold season, even though the concentrations of bacteriophages in water samples were similar throughout the experiment. See Tables 1 and 2 for the MS2 and E. coli concentration in water samples after each irrigation. These details tell us that there were bacteria and phages alive during the time course of the experiment. 
Table 1. MS2 PFU in the irrigation water samples.

\begin{tabular}{|c|c|c|c|c|c|c|c|c|c|}
\hline \multirow{2}{*}{ Day } & \multirow{2}{*}{ Date } & \multicolumn{2}{|c|}{ Dilution } & \multicolumn{2}{c|}{ Dilution } & \multicolumn{2}{c|}{ Dilution } & \multicolumn{2}{c|}{ Dilution } \\
\cline { 3 - 11 } & & \multicolumn{2}{|c|}{$10^{-3}$} & \multicolumn{2}{|c}{$10^{-4}$} & \multicolumn{2}{|c|}{$10^{-5}$} & \multicolumn{2}{c|}{$10^{-6}$} \\
\hline 1 & $11 / 20 / 19$ & TNTC & TNTC & 247 & 309 & 33 & 48 & 9 & 3 \\
\hline 2 & $11 / 21 / 19$ & TNTC & TNTC & 268 & 348 & 35 & 39 & 12 & 5 \\
\hline 3 & $11 / 22 / 19$ & TNTC & TNTC & 248 & 256 & 51 & 46 & 8 & 7 \\
\hline 4 & $11 / 23 / 19$ & TNTC & TNTC & 228 & 248 & 42 & 47 & 9 & 9 \\
\hline 5 & $11 / 24 / 19$ & TNTC & TNTC & 116 & 200 & 56 & 51 & 6 & 4 \\
\hline 6 & $11 / 25 / 19$ & - & TNTC & 113 & 101 & 12 & 6 & 0 & 0 \\
\hline 7 & $11 / 26 / 19$ & - & TNTC & 112 & 140 & 15 & 15 & 0 & 0 \\
\hline 8 & $11 / 27 / 19$ & - & TNTC & 171 & 205 & 26 & 26 & 0 & 0 \\
\hline 9 & $11 / 28 / 19$ & - & 392 & 83 & 87 & 3 & 7 & 0 & 0 \\
\hline 10 & $11 / 29 / 19$ & - & TNTC & 81 & 80 & 6 & 19 & 0 & 0 \\
\hline 11 & $11 / 30 / 19$ & - & TNTC & 113 & 115 & 15 & 8 & 0 & 0 \\
\hline 12 & $12 / 01 / 19$ & - & 416 & 53 & 29 & 5 & 3 & 0 & 0 \\
\hline
\end{tabular}

See Tables 3 and 4 for the MS2 assay results of plant surfaces and plant tissue. As can be seen from these tables, there were no detectable levels of MS2 in either the plant tissues or plant surface samples, indicating that there was no movement of this pathogen from the soil water to the above-ground portion of the plants.

Results from the Quanti-Tray/2000 system are designed to give quantified bacterial counts of $100 \mathrm{~mL}$ samples using IDEXX reagent products. No positive large and small wells were found to use the Most Probable Number (MPN) tables to determine the MPN of bacteria. Results indicated the absence of $E$. coli in both plant surfaces and plant tissue of the control and treated groups. None of the samples were fluorescent under UV light for E. coli detection. 
Table 2. Titer of E. coli. \# of colonies in the irrigation water samples.

\begin{tabular}{|c|c|c|c|c|c|c|c|c|c|c|c|}
\hline \multirow{2}{*}{ Day } & \multirow{2}{*}{ Date } & \multicolumn{2}{|c|}{ Dilution } & \multicolumn{2}{c|}{ Dilution } & \multicolumn{2}{c|}{ Dilution } & \multicolumn{2}{c|}{ Dilution } & \multicolumn{2}{c|}{ Dilution } \\
\cline { 3 - 14 } & & \multicolumn{2}{|c|}{$10^{-1}$} & \multicolumn{2}{|c|}{$10^{-2}$} & \multicolumn{2}{|c|}{$10^{-3}$} & \multicolumn{2}{|c|}{$10^{-4}$} & \multicolumn{2}{c|}{$10^{-5}$} \\
\hline 1 & $11 / 20 / 19$ & TNTC & TNTC & TNTC & TNTC & TNTC & TNTC & 369 & 333 & 61 & 52 \\
\hline 2 & $11 / 21 / 19$ & TNTC & TNTC & TNTC & TNTC & TNTC & TNTC & 292 & 271 & 103 & 159 \\
\hline 3 & $11 / 22 / 19$ & TNTC & TNTC & TNTC & TNTC & TNTC & TNTC & 288 & 306 & 66 & 75 \\
\hline 4 & $11 / 23 / 19$ & TNTC & TNTC & TNTC & TNTC & TNTC & TNTC & 228 & 212 & 67 & 64 \\
\hline 5 & $11 / 24 / 19$ & TNTC & TNTC & TNTC & TNTC & TNTC & TNTC & 299 & 268 & 59 & 70 \\
\hline 6 & $11 / 25 / 19$ & - & - & - & - & - & TNTC & 271 & 229 & 77 & 69 \\
\hline 7 & $11 / 26 / 19$ & - & - & - & - & - & TNTC & 249 & 288 & 81 & 79 \\
\hline 8 & $11 / 27 / 19$ & - & - & - & - & - & 356 & 212 & 279 & 89 & 84 \\
\hline 9 & $11 / 28 / 19$ & - & - & - & - & - & TNTC & 140 & 160 & 98 & 30 \\
\hline 10 & $11 / 29 / 19$ & - & - & - & - & - & 389 & 94 & 109 & 36 & 24 \\
\hline 11 & $11 / 30 / 19$ & - & - & - & - & - & 424 & 66 & 77 & 15 & 17 \\
\hline 12 & $12 / 01 / 19$ & - & - & - & - & - & TNTC & 236 & 245 & 99 & 80 \\
\hline
\end{tabular}

Table 3. MS2 assay results (PFU): treated (T) and Control (C) group, Plant tissues (N) locations.

\begin{tabular}{|c|c|c|c|c|c|c|c|c|c|c|c|}
\hline \multicolumn{2}{|c|}{ Sample } & \multicolumn{2}{c|}{$\begin{array}{c}\text { Plate } 1 \\
\text { \# plaques }\end{array}$} & $\begin{array}{c}\text { Plate } 2 \\
\text { \# plaques }\end{array}$ & \multicolumn{2}{c|}{$\begin{array}{c}\text { Plate } 3 \\
\text { \# plaques }\end{array}$} & \multicolumn{2}{c|}{$\begin{array}{c}\text { Plate } 4 \\
\text { \# plaques }\end{array}$} & \multicolumn{2}{c|}{$\begin{array}{c}\text { Plate } 5 \\
\text { \# plaques }\end{array}$} \\
\hline $1 \mathrm{TN}$ & $1 \mathrm{CN}$ & 0 & 0 & 0 & 0 & 0 & 0 & 0 & 0 & 0 & 0 \\
\hline $2 \mathrm{TN}$ & $2 \mathrm{CN}$ & 0 & 0 & 0 & 0 & 0 & 0 & 0 & 0 & 0 & 0 \\
\hline $3 \mathrm{TN}$ & $3 \mathrm{CN}$ & 0 & 0 & 0 & 0 & 0 & 0 & 0 & 0 & 0 & 0 \\
\hline $4 \mathrm{TN}$ & $4 \mathrm{CN}$ & 0 & 0 & 0 & 0 & 0 & 0 & 0 & 0 & 0 & 0 \\
\hline $5 \mathrm{TN}$ & $5 \mathrm{CN}$ & 0 & 0 & 0 & 0 & 0 & 0 & 0 & 0 & 0 & 0 \\
\hline $6 \mathrm{TN}$ & $6 \mathrm{CN}$ & 0 & 0 & 0 & 0 & 0 & 0 & 0 & 0 & 0 & 0 \\
\hline $7 \mathrm{TN}$ & $7 \mathrm{CN}$ & 0 & 0 & 0 & 0 & 0 & 0 & 0 & 0 & 0 & 0 \\
\hline $8 \mathrm{TN}$ & $8 \mathrm{CN}$ & 0 & 0 & 0 & 0 & 0 & 0 & 0 & 0 & 0 & 0 \\
\hline $9 \mathrm{TN}$ & $9 \mathrm{CN}$ & 0 & 0 & 0 & 0 & 0 & 0 & 0 & 0 & 0 & 0 \\
\hline
\end{tabular}


Table 4. MS2 Assay results (PFU). Treated (T) and Control (C) group, Plant surfaces (X) locations.

\begin{tabular}{|c|c|c|c|c|c|c|c|c|c|c|c|}
\hline \multicolumn{2}{|c|}{ Sample } & \multicolumn{2}{c|}{$\begin{array}{c}\text { Plate 1 } \\
\text { \# plaques }\end{array}$} & $\begin{array}{c}\text { Plate 2 } \\
\text { \# plaques }\end{array}$ & $\begin{array}{c}\text { Plate 3 } \\
\text { \# plaques }\end{array}$ & \multicolumn{2}{c|}{$\begin{array}{c}\text { Plate 4 } \\
\text { \# plaques }\end{array}$} & \multicolumn{2}{c|}{$\begin{array}{c}\text { Plate 5 } \\
\text { \# plaques }\end{array}$} \\
\hline $1 \mathrm{TX}$ & $1 \mathrm{CX}$ & 0 & 0 & 0 & 0 & 0 & 0 & 0 & 0 & 0 & 0 \\
\hline $2 \mathrm{TX}$ & $2 \mathrm{CX}$ & 0 & 0 & 0 & 0 & 0 & 0 & 0 & 0 & 0 & 0 \\
\hline $3 \mathrm{TX}$ & $3 \mathrm{CX}$ & 0 & 0 & 0 & 0 & 0 & 0 & 0 & 0 & 0 & 0 \\
\hline $4 \mathrm{TX}$ & $4 \mathrm{CX}$ & 0 & 0 & 0 & 0 & 0 & 0 & 0 & 0 & 0 & 0 \\
\hline $5 \mathrm{TX}$ & $5 \mathrm{CX}$ & 0 & 0 & 0 & 0 & 0 & 0 & 0 & 0 & 0 & 0 \\
\hline $6 \mathrm{TX}$ & $6 \mathrm{CX}$ & 0 & 0 & 0 & 0 & 0 & 0 & 0 & 0 & 0 & 0 \\
\hline $7 \mathrm{TX}$ & $7 \mathrm{CX}$ & 0 & 0 & 0 & 0 & 0 & 0 & 0 & 0 & 0 & 0 \\
\hline $8 \mathrm{TX}$ & $8 \mathrm{CX}$ & 0 & 0 & 0 & 0 & 0 & 0 & 0 & 0 & 0 & 0 \\
\hline $9 \mathrm{TX}$ & $9 \mathrm{CX}$ & 0 & 0 & 0 & 0 & 0 & 0 & 0 & 0 & 0 & 0 \\
\hline
\end{tabular}

Thus, the use of subsurface irrigation can be an alternative technique for safer irrigation with contaminated water as it was suggested by Slack et al [22]. Other irrigation methods such as surface, sprinkler, or conventional drip irrigation represents a significant public health concern due to the presence of multiple microbial pathogens associated with gastrointestinal disease. The results obtained shown that SDI systems can reduce health risks from reclaimed water use by minimizing the exposure of the irrigation water to people or agricultural produce. These results were in agreement with the results from earlier studies [20],[23-25]. Since irrigation water does never reached the soil surface due to direct irrigation to the crop root zone, the exposure of irrigation water to produce was be minimized. This could be since the soil acted as a living filter to remove pathogenic microorganisms as described by Oron et al. [24]. Enriquez et al. [20] studied turfgrass contamination by comparing subsurface drip irrigation with sprinkler irrigation when tertiary effluent seeded with coliphages of MS2 and PRD-1 were used for irrigation water. The numbers of coliphages in the clippings collected from the subsurface irrigated plots were minimal. In contrast, both coliphages were found in large numbers in the clippings from the sprinkler irrigated plots. According to Alum et al. [25], no above-ground surface contamination of tomato crops was observed with subsurface drip irrigation, while the surface irrigation resulted in surface contamination of leaves and fruits of tomato.

\section{Conclusions}

The present study evaluated subsurface irrigation relative to the potential for crop contamination by two surrogate microorganisms, E. coli and MS2. None of the study microorganisms were recovered from lettuce at plant tissues or plant surfaces. Subsurface irrigation with proper management showed great potential in reducing crop contamination when microbial-contaminated water is used for irrigation water. It suggests that an installation depth of drip tapes $(20 \mathrm{~cm})$ for an SDI system and more frequent irrigations eliminate soil surface wetting in subsurface drip-irrigated plots and reduce potential contamination. Such practices may guarantee dry surfaces and can be particularly useful to prevent health risks when contaminated water is used for irrigation. The results obtained in 
this study suggest that subsurface irrigation may provide a great alternative in comparison to other irrigation techniques when resources and the infrastructure may limit the use of extensively treated wastewater effluents.

This work was supported by funds from the Department of Biosystems Engineering (BE) and the Water \& Energy Sustainable Technology (WEST) Center, both at the University of Arizona. The authors would like to thank Patricia Gundy, Principal Research Specialist, and Dr. Kelly Bright, Research Professor, both of the WEST center and the Environmental Science Department at the University of Arizona. Their cooperation, suggestions, and training at the lab were essential in this study. The authors would also like to thank the Assistant Research Professors, Research Technicians, students at the WEST, and Chapingo students for their assistance with the lab procedures and results collection.

\section{References}

1. J.C. Heaton, K. Jones, J. Appl. Microbiol 104, 613-626 (2008)

2. [CDC] Centers for Disease Control and Prevention. Foodborne disease outbreak 2018 case definition. Available from: https://www.cdc.gov/ecoli/2018/o157h7-0418/?fbclid=IwAR3o0EC AhIIv1317ixJgiCci63ayZxih3DD2bYwrx7oLe3cHWWgUjD pWTw. Accessed February 13, 2020.

3. E.A. Bihn, R.B. Gravani, In K. R. Matthews (ed.), Microbiology of fresh produce 21 53 (2006)

4. E.B. Solomon, S. Yaron, K.R. Matthews, Appl. Environ. Microbiol 68, 397-400 (2002)

5. E.B. Solomon, H.-J. Pang, K.R. Matthews, J. Food Prot 66, 2198-2202 (2003)

6. E.B. Solomon, M.T. Brandl, R.E. Mandrell, In K. R. Matthews (ed.), Microbiology of fresh produce $55-83$ (2006)

7. E.Franz, A.A. Visser, A.D. van Diepeningen, M.M. Klerks, A.J. Termoshuizen, and A. H.C. van Bruggen, Food Microbiol 24, 106-112 (2007)

8. M.R. Wachtel, L.C. Whitehand, R.E. Mandrell, J. Food Prot 65, 471-475 (2002)

9. R.Hora, K.Warrnier, B.J. Shelp, and M.W. Griffiths, J. Food Prot 68, 2506-2509 (2005)

10. J. Jablastone, K. Warrnier, and M. W. Griffiths. 2005. Int. J. Food Microbiol 99, 7-18 (2005)

11. P. Delaquis, S. Bach, L.-D. Dinu, J. Food Prot. 70, 1966-1974 (2007)

12. M.T. Brandl, and R. Amundson, Appl. Environ. Microbiol 74, 2298-2306 (2008)

13. K. Herman, Ayers, T. L., \& Lynch, M. Foodborne disease outbreaks associated with leafy greens, In Proceedings of the International Conference on Emerging Infectious Diseases, 16-19 March 2008, Atlanta, USA

14. T.T. Fong, E.K. Lipp, Microbiol. Mol. Biol. Rev 69(2), 357-371 (2005)

15. J.T. Tierney, R. Sullivan, and E.P. Larkin, Appl. Environ. Microbiol 33, 109-113 (1977)

16. B.K. Ward, L.G. Irving, Water Res., 21, 57 (1987)

17. M.A. Smith, Australian Government Public Service. (Canberra, Australia, 1982)

18. A. Absar, C.E. Enriquez, G. Oron, and C.P. Gerba, Water reuse (The University of Arizona, 2000)

19. R.G. Sinclair, J.B. Rose, S.A. Hashsham, C.P. Gerba, C.N. Haas, Appl. Environ. Microbiol 78(6), 1969-1977 (2012)

20. C. Enriquez, A. Alum, E.M. Suarez-Rey, C.Y. Choi, G. Oron, C.P. Gerba, Journal of Environmental Engineering 129(9), 852-857 (2003) 
21. D.J. Dawson, A. Paish, L.M. Staffell, I.J. Seymour, H. Appleton, Journal of applied microbiology 98(1), 203-209 (2005)

22. S.M. Slack, G.W. Sundin, New york horticultural society fruit quarterly 25(1), 9-12 (2017)

23. G. Oron, Y. DeMalach, Z. Hoffman, (1992). Water Sci. Technol 26(7-8), 1593-1601 (1992)

24. G. Oron, M. Geomans, Y. Manor, J. Feyen, Water Res 29(4), 1069-1078 (1995)

25. A. Alum, C. E. Enriquez, G. Oron, and C.P. Gerba, J. Am. Wat. Wks Assoc. San Antonio (2000) 